\title{
PELATIHAN DAN PENDAMPINGAN PETANI CABAI DALAM PENGOLAHAN CABAI KERING DI DESA BOCEK, KECAMATAN KARANGPLOSO, KABUPATEN MALANG
}

\section{TRAINNING AND ASSISTANCE THE CHILLI FARMER TO PROCESS DRYING CHILLI IN BOCEK VILLAGE, KARANGPLOSO DISTRICT, MALANG REGENCY}

\author{
Evi Nurifah Julitasari ${ }^{1 *}$, Emma Budi Sulistiarini ${ }^{2}$, Yovita Serat Payon ${ }^{1}$ \\ ${ }^{1}$ Program Studi Agribisnis, Fakultas Pertanian, Universitas Widyagama Malang \\ ${ }^{2}$ Program Studi Teknik Industri, Fakultas Teknik, Universitas Widyagama Malang \\ *Email: nurifah_uwg@yahoo.co.id
}

(Diterima 17-02-2021; Disetujui 17-03-2021)

\begin{abstract}
ABSTRAK
Pandemi Covid-19, berdampak pada perekonomian, juga terhadap petani cabai. Harga cabai yang turun drastis menyebabkan petani menderita kerugian, hal ini disebabkan cabai segar tidak terserap seluruhnya oleh industri makanan, restoran maupun konsumsi masyarakat. Penurunan harga ini harus diimbangi dengan pengolahan menjadi produk lain yang mempunyai nilai tambah tinggi, misalnya pengolahan cabai kering, abon cabai, dan lain sebagainya. Namun, sayangnya kemampuan petani untuk mengolah menjadi cabai olahan masih terbatas, oleh karena itu, tim mengadakan pelatihan dan pendampingan dalam pengolahan cabai segar menjadi cabai kering. Kelompok sasaran adalah petani yang tergabung dalam kelompok tani Manggisari, yang terletak di desa Bocek Kecamatan Karangploso Kabupaten Malang, sebagai salah satu sentra penghasil cabai di Kabupaten Malang. Pelatihan yang didukung oleh LPPM Universitas Widyagama Malang dengan melibatkan mahasiswa program studi Agrobisnis, diharapkan dapat memberi inspirasi, untuk mengolah cabai hasil panennya menjadi cabai kering. Sebelumnya dilakukan penyuluhan dengan memberi pemahaman bahwa harga cabai olahan lebih tinggi dari pada dijual segar atau akan memberi nilai tambah kurang lebih Rp 10.000/kg. Harapannya dengan memberi hasil perhitungan petani akan mempercayainya (seeing is believing). Program ini akan dilanjutkan secara terus menerus, khususnya pada kelompok tani wanita (KWT) untuk secara berkelompok melakukan pelatihan pembuatan cabai kering.
\end{abstract}

Kata kunci : Dampak Covid-19, Pengolahan Cabai kering, Pelatihan dan Pendampingan

\section{ABSTRACT}

The Covid-19 pandemic has an impact on the economy, also on chilli farmers. The drastic drop in chili prices caused farmers to suffer losses, this is because fresh chilies are not fully absorbed by the food industry, restaurants and public consumption. This price reduction must be balanced with processing into other products that have high added value, for example the processing of dry chilies, shredded chilies and so on. But unfortunately the farmer's ability to process chilies into processed chilies is still limited, therefore our team held training and assistance in processing fresh chilies into dried chilies. Our target group is farmers who are members of the Manggisari farmer group, which is located in Bocek Village, Karangploso District, Malang Regency, as one of the chilli producing centers in Malang Regency. The training, which is supported by LPPM Widyagama University Malang by involving students of the Agribusiness study program, is expected to provide inspiration, to process the chilies they harvest into dried chilies. Previously, counseling was carried out by providing an understanding that the price of processed chilies was higher than sold fresh or would add an added value of approximately Rp. 10,000/ kg. The hope is that by giving the results of calculations, farmers will believe it (seeing is believing). This program will be continued continuously and especially for women farmer groups (KWT) to conduct training in groups to make dry chilies.

Keywords: Covid-19 Impact, Dry Chili Processing, Training and Assistance

\section{PENDAHULUAN}

Pandemi Covid-19 yang terjadi mulai bulan Februari 2020, benar-benar berdampak pada semua sektor termasuk pertanian dan agroindustrinya. Pertumbuhan ekonomi dunia 
Pelatihan dan Pendampingan Petani Cabai dalam Pengolahan Cabai Kering di Desa Bocek, Kecamatan Karangploso, Kabupaten Malang

Evi Nurifah Julitasari, Emma Budi Sulistiarini, Yovita Serat Payon

turun hingga hanya 3\%, dan menurut Menkeu RI Sri Mulyani, pertumbuhan ekonomi Indonesia akan turun menjadi $2,3 \%$ bahkan negatif $0,4 \%$. Hal ini disebabkan menurunnya konsumsi rumah tangga 3,2\% hingga 1,2\%, dan tutupnya sektor-sektor strategis seperti hotel, pertokoan, dan sebagainya.

Pada masa pandemi Covid-19, harga-harga produk pertanian justru turun demikian drastis. Hal ini disebabkan oleh berhentinya sektor non-pertanian lainnya seperti hotel restoran dan pariwisata, akibatnya pula harga cabai menurun. Menurut Dinas Perindustrian dan Perdagangan Jawa Timur, sebelum Covid rata-rata harga cabai mencapai Rp 45.694 per-kilogram di tingkat konsumen, di wilayah Surabaya berada di kisaran Rp 46.400 perkilogram. Namun saat ini, harga rata-rata cabai merah besar berada di angka Rp 22.400 per-kilogram dan untuk wilayah Surabaya dibanderol seharga Rp 23.007 per-kilogram, hal ini turun hampir $50 \%$ lebih (Wijayanto, 2020).

Harga di tingkat petani dan pedagang besar tentu lebih rendah, hanya sekitar Rp 15.000 per-kilogram, bahkan ada juga Rp 11.000 per-kilogram. Kondisi ini sangat merugikan petani cabai, karena meningkatnya biaya-biaya produksi dan upah tenaga kerja mulai dari tanam hingga panen. Oleh karena itu, perlu peningkatan nilai tambah dari produk cabai basah menjadi produk cabai kering sehingga mempanjang umur simpan dan tentu akan menstabilkan harga cabai. Usaha kecil/UMKM yang menyerap hasil panen cabai menjadi produk olahan cabai kering untuk meningkatkan nilai tambah (additional value) masih relatif sedikit.

Untuk itu, tim bekerja sama dengan Kelompok Tani Manggisari yang terletak di Desa Bocek, Kecamatan Karangploso. Petani cabai di desa ini kurang lebih terdapat 500 KK, yang tersebar di dusun-dusun. Petani biasanya mulai menanam cabai pada bulan 11 (November), dengan umur tanam ada yang 90 hari atau 120 hari, dengan rata-rata 12 kali petik cabai selama tanam, setelah cabai umur 20 hari setelah tanam (HST). Melihat potensi produksi petani cabai ini, maka pembuatan cabai kering akan sangat memberi nilai tambah pada petani. Terutama pada saat harga cabai murah dan terjadinya kelebihan produk (over supply) dari petani cabai.

Banyaknya petani yang belum mengetahui bagaimana cara mengolah dari cabai basah menjadi cabai kering mendasari pelaksanaan pengabdian kepada masyarakat ini.

\section{BAHAN DAN METODE}

Pelaksanaan pengabdian masyarakat ini dilakukan di dusun Supiturang, desa Bocek kecamatan Karangploso, kabupaten Malang. Pengabdian dilakukan kepada 
kelompok tani Manggisari, yang terdiri atas 30 orang petani, disamping itu ada kelompok tani Mekarsari, yang terdiri atas 30 orang petani. Tim memilih kelompok tani Manggisari, disebabkan aktivitas kelompok tani ini rutin mengadakan pertemuan dua kali setiap bulan. Pada pertemuan awal dilakukan penyuluhan atau sosialisasi kepada petani baru kemudian melakukan pelatihan dan pendampingan. Selain kelompok tani, juga dilibatkan UMKM Cece Rahayu, yang bergerak pada pengolahan cabai kering dan kopi. UMKM “Cece Rahayu” mulai berproduksi April 2020, hal ini karena melihat dampak terjadinya wabah global Covid-19, banyak tenaga kerja yang dirumahkan dan harga cabai yang sangat murah.

Metode pelaksanaan pengabdian masyarakat ini dimulai dengan: (1) Sosialisasi ke petani yang tergabung dalam kelompok tani Manggisari, dan (2) Demontrasi pembuatan Cabai Kering dengan melibatkan mahasiswa. Pelaksakan penyuluhan dan pendampingan dilakukan pada bulan Oktober sampai September 2020.

\section{HASIL DAN PEMBAHASAN}

Berdasarkan permasalahan yang ada di kelompok tani, maka tim melakukan sosialisasi dengan mengadakan pertemuan langsung (offline) dengan anggota kelompok tani. Di sini dapat diketahui bahwa sebagian besar petani mengeluhkan adanya penuruhan harga cabai yang sangat drastis, bahkan upah petik mencapai Rp 40.000,-. untuk setiap 10 kg cabai. Padahal harga cabai ditingkat petani rata-rata hanya Rp 4.000/kg, sehingga petani cabai akan sangat merugi.

Oleh karena itu, dengan dibantu mahasiswa dapat memberi gambaran kepada petani bahwa pengolahan cabai basah menjadi cabai kering akan sangat meningkatkan pendapatan petani. Berdasarkan analisis usaha tani selama ini, apabila dikonversikan dalam hektar, rata-rata biaya produksi adalah $\mathrm{Rp} 24.295 .000 /$ ha, dengan pendapatan kotor ratarata $\mathrm{Rp} \mathrm{40.000.000/ha,} \mathrm{harga} \mathrm{yang} \mathrm{dipakai} \mathrm{adalah} \mathrm{Rp} 5.000 / \mathrm{kg}$ di tingkat petani dengan produksi cabai rata-rata 8 ton per hektar, maka penerimaan bersih rata-rata sebesar Rp 15.705.000/tahun/hektar. Jika dibagi dalam setahun rata-rata penerimaan bersih petani cabai sebesar Rp 1.308.000/bulan. Dengan mengolah cabai menjadi cabai kering gelondongan maka diperoleh nilai tambah sebesar $\mathrm{Rp} 10.040 / \mathrm{kg}$ artinya pendapatan meningkat dengan tambahan Rp 10.040/kg. Adapun nilai konversi yang digunakan adalah 0,112 artinya setiap $10 \mathrm{~kg}$ cabai basah dihasilkan $1,2 \mathrm{~kg}$ cabai kering glondongan (Julitasari, 2020). 
Pelatihan dan Pendampingan Petani Cabai dalam Pengolahan Cabai Kering di Desa Bocek, Kecamatan Karangploso, Kabupaten Malang

Evi Nurifah Julitasari, Emma Budi Sulistiarini, Yovita Serat Payon

Pembuatan cabai kering memang belum banyak dikenal petani apalagi petani pada umumnya langsung menjual segar ke pasar atau tengkulak. Berikut ini, dokumentasi dari pertemuan dengan petani anggota kelompok tani Manggisari.

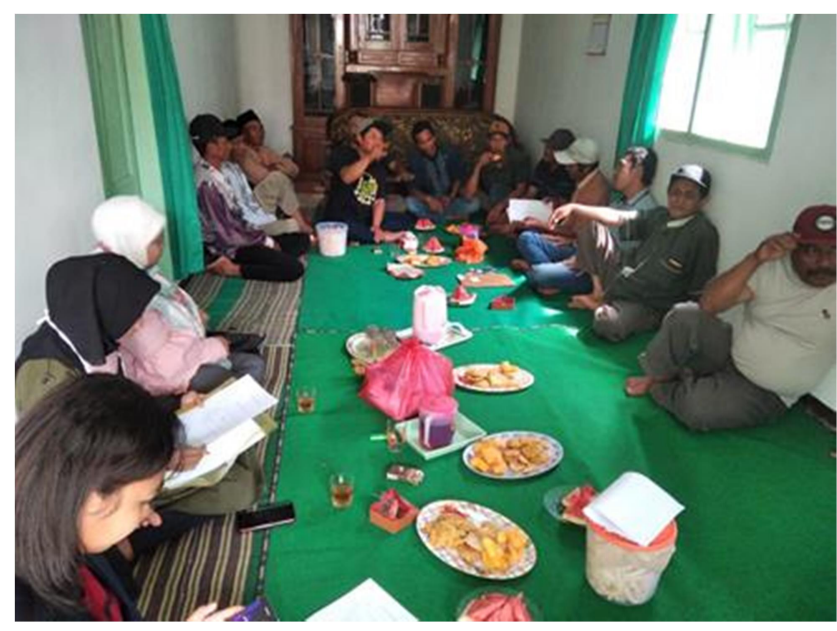

Gambar 1. Penyuluhan dan Sosialisasi Pembuatan Cabai Kering

\section{Pengolahan Cabai Kering}

Ada 2 (dua) bentuk akhir dari agroindustri cabai kering, yaitu 1) Cabai Kering Utuh (glondongan), dan 2) Abon Cabai. Perbedaannya pada cabai kering glondongan bentuk cabai masih utuh dan tidak ada perlakuan lainnya sedangkan abon cabai, biasanya diberi bumbu tambahan seperti bawang putih, bawang merah, ebi, keju, dan lain-lain. Tentunya disini ada tambahan pekerjaan untuk memproduksinya. Berikut ini adalah contoh produk cabai kering dalam bentuk glondongan yang dihasilkan UMKM Cece Rahayu, disajikan pada Gambar 2.

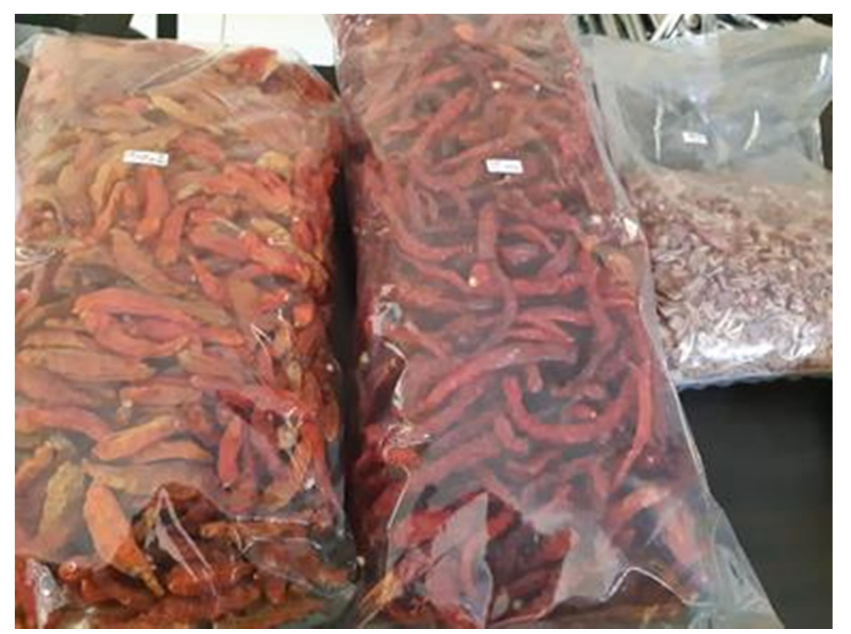

Gambar 2. Cabai Kering Besar dan Kecil dalam bentuk Glondongan 
Cabai kering utuh sebagaimana disajikan Gambar 3 merupakan bahan baku pembuatan Abon Cabai setelah ditambahkan bawang putih, bawang merah, garam, gula, kaldu, teri, dan ebi. Bumbu-bumbu ini pada dasarnya bertujuan untuk memberikan aroma, rasa yang dapat membangkitkan selera makan dan sebagai pengawet. Produksinya ada bermacam-macam khususnya abon cabai ada 3 varian, yaitu (1) Abon Cabai Jegrik (Sangat Pedas) dengan rasa original, Ebi dan Teri, (2) Abon Cabai (Pedas) dengan rasa original, Ebi dan Teri (3) Bawang bubuk. Produk abon cabai dengan berbagai varian, disajikan pada Gambar 3.

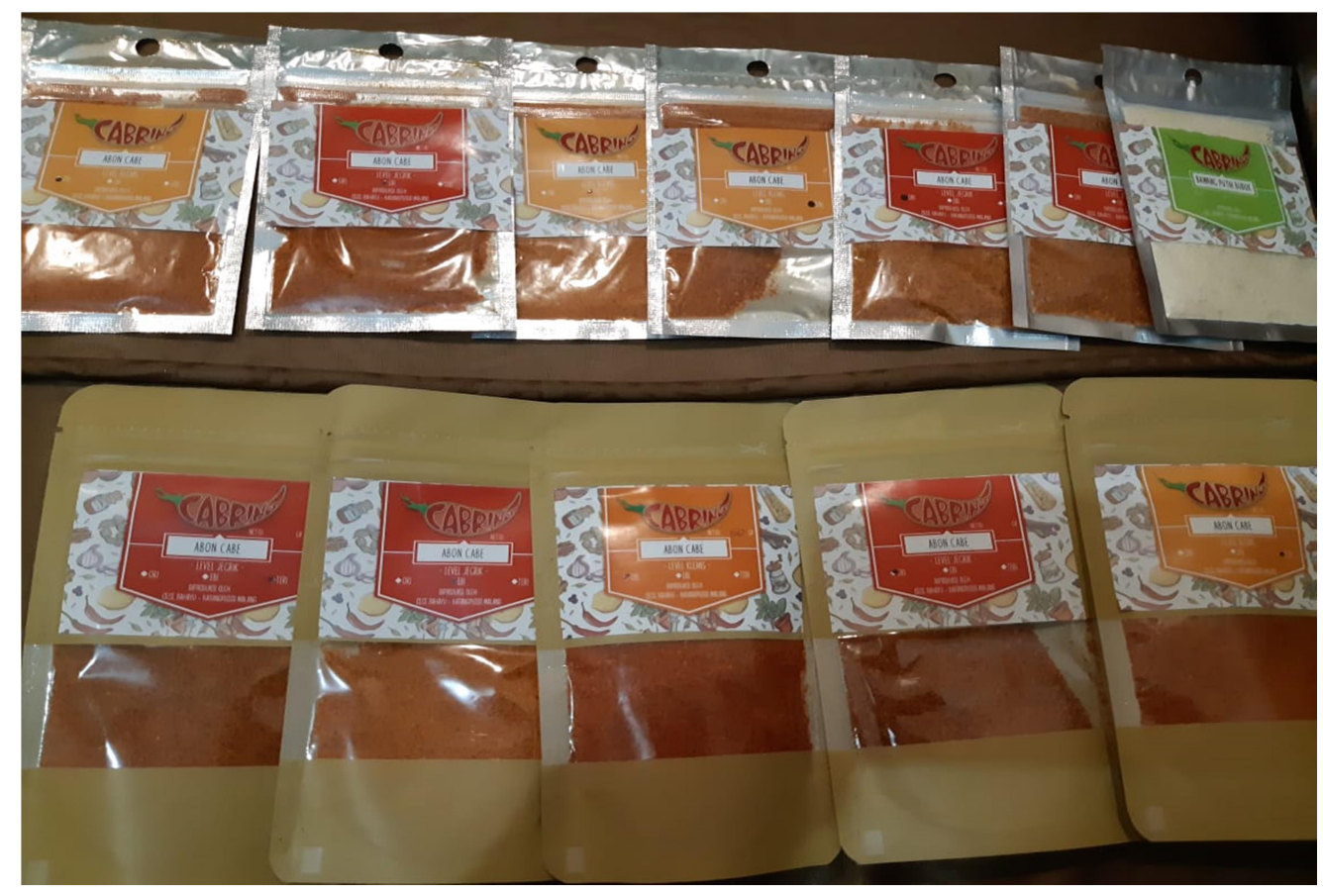

Gambar 3. Produk Abon Cabai dengan Berbagai Varian Rasa

Proses pengolahan cabai kering memerlukan alat dan bahan serta langkah-langkah sebagai berikut. Alat-alat yang dibutuhkan dalam proses pembuatan cabai kering:

1. Timbangan: digunakan untuk mengukur berat (timbangan) yang sudah distel atau yang sudah dikalibrasi.

2. Oven: digunakan untuk mengeringkan cabai segar atau cabai basah menjadi cabai kering. Bisa juga menggunakan sumber tenaga panas lain yaitu sinar matahari.

3. Kompor: digunakan pada saat pengukusan cabai segar dan pemasakan (sangrai) cabai yang sudah dihaluskan.

4. Dandang: digunakankan untuk mengukus cabai.

5. Teflon: digunakan untuk menyangrai cabai yang sudah dihaluskan (abon cabai).

6. Ember: digunakan untuk blanching atau mencuci cabai sebelum dikeringkan. 
Pelatihan dan Pendampingan Petani Cabai dalam Pengolahan Cabai Kering di Desa Bocek, Kecamatan Karangploso, Kabupaten Malang

Evi Nurifah Julitasari, Emma Budi Sulistiarini, Yovita Serat Payon

7. Sealer: untuk pengemasan.adalah aluminium foil dan kraft paper.

Langkah-langkah pengolahan cabai kering dilakukan sebagai berikut:

a. Seleksi Bahan / Penyiapan Bahan

Seleksi bahan dilakukan untuk membedakan cabai yang masih baik dan kurang baik, yaitu yang masih segar dan yang sudah layu dan busuk. Cabai besar dan cabai rawit masih segar dan berwarna merah. Penentuan mutu bahan didasarkan pada kesegaran, bentuk, kebebasan dari benda asing dan penyakit. Jika cabai yang digunakan mutunya baik maka diharapkan produk abon cabai yang dihasilkan juga berkualitas. Evaluasi mutu dilakukan untuk menjaga supaya cabai yang digunakan dapat sesuai dengan syarat mutu yang ditetapkan oleh perusahaan, sehingga dihasilkan abon cabai yang sesuai dengan standar mutu yang ditetapkan (Kamarijani, 1983).

\section{b. Pencucian Bahan}

Pembersihan dilakukan menggunakan air yang bersih yang mengalir supaya benarbenar bersih dan menghilangkan kotoran yang menempel pada cabai. Proses pencucian cabai menggunakan air bersih kemudian cabai dipetik tangkainya. Proses pembersihan disajikan pada Gambar 4.
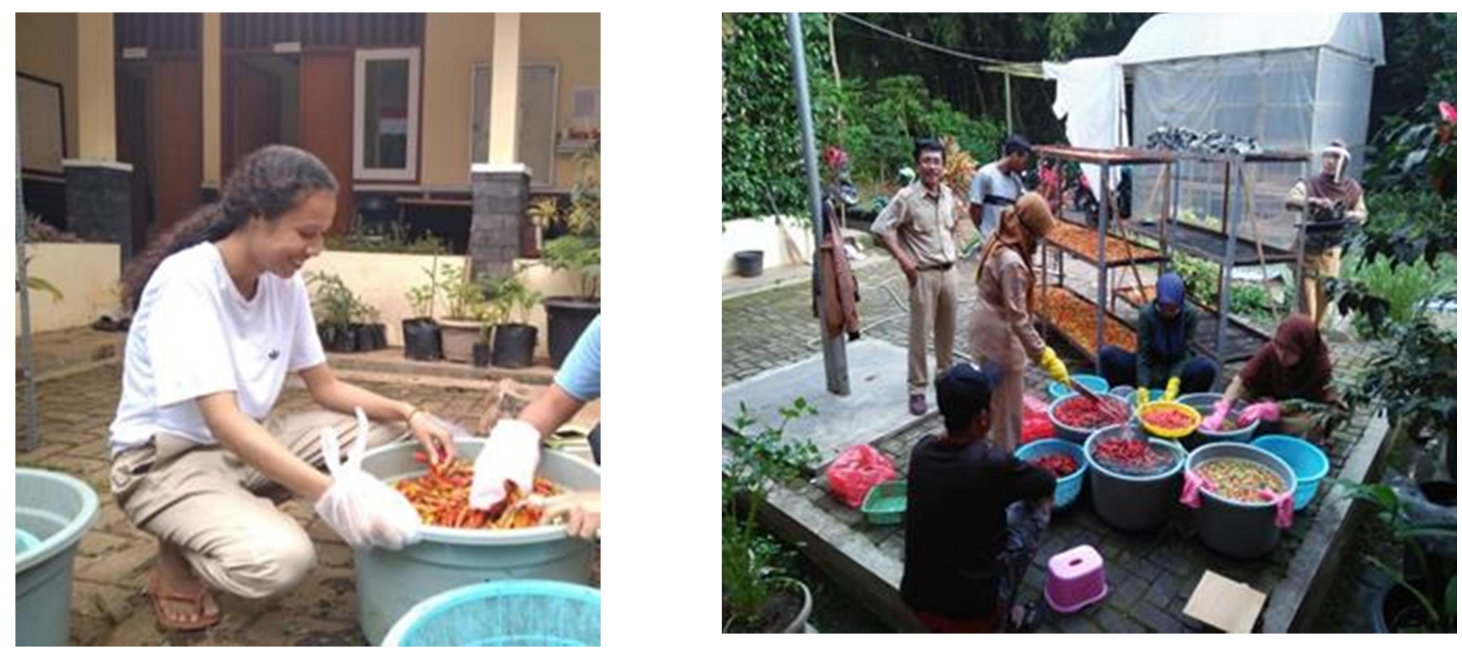

Gambar 4. Demo Proses Pencucian Cabai Segar Bersama Kelompok Masyarakat

\section{c. Penimbangan}

Penimbangan bahan harus dilakukan dengan benar supaya tidak terjadi kesalahan dalam penggunaan jumlah bahan. Penimbangan dilakukan setelah cabai dikeringkan. Bahan tambahan makanan merupakan bahan yang dibutuhkan dalam jumlah sedikit, tetapi sangat penting supaya dihasilkan produk yang berkualitas baik sehingga harus diukur dengan teliti. Dalam penimbangan sebaiknya tidak menggunakan sendok atau cangkir sebagai takaran (Setyo, 2004). 


\section{d. Pemasakan}

Tahap pemasakan adalah tahap yang paling kritis. Pemasakan bertujuan untuk menghilangkan bau mentah. Pemasakan dilakukan dengan suhu yang tidak terlalu rendah maupun tidak terlalu tinggi. Sebaliknya suhu yang terlalu tinggi membuat bahan menjadi hangus (Desroiser, 2008). Cabai dikukus selama kurang lebih 5 (lima) menit. Tujuannya agar cabai tidak mudah busuk, kemudian cabai langsung ditiriskan. Proses pemasakan cabai disajikan Gambar 5.
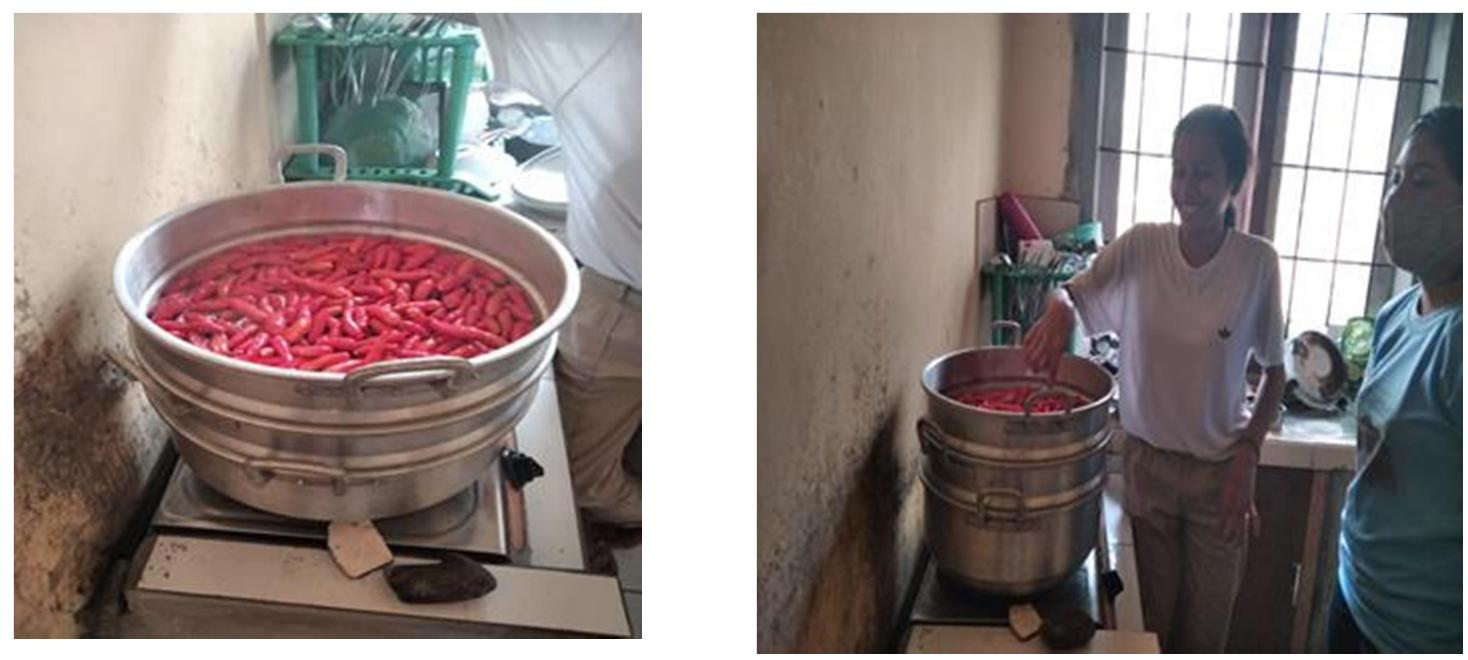

\section{Gambar 5. Demo Proses Perebusan Cabai}

\section{e. Pengeringan Bahan}

Metode pengeringan abon cabai yang telah dikenal adalah pengeringan dengan memanfaatkan panas matahari secara langsung dan pengeringan mekanis menggunakan alat pengering yang dirancang khusus. Aman et al (1992) melaporkan bahwa keunggulan pengeringan vakum dibandingkan dengan pengeringan lainnya adalah proses pengeringan berlangsung lebih cepat. Thjahjadi dan Marta (2011) mengungkapkan bahwa pengeringan dengan menggunakan sinar matahari memiliki kekurangan seperti mudah terkontaminasi dengan berbagai kotoran, panasnya tergantung pada pancaran sinar matahari, dan laju pengeringan lambat. Berikut pada Gambar 6 terlihat alat pengeringan sedehana dengan sinar matahari yang bisa dilakukan oleh petani. 
Pelatihan dan Pendampingan Petani Cabai dalam Pengolahan Cabai Kering di Desa Bocek, Kecamatan Karangploso, Kabupaten Malang Evi Nurifah Julitasari, Emma Budi Sulistiarini, Yovita Serat Payon
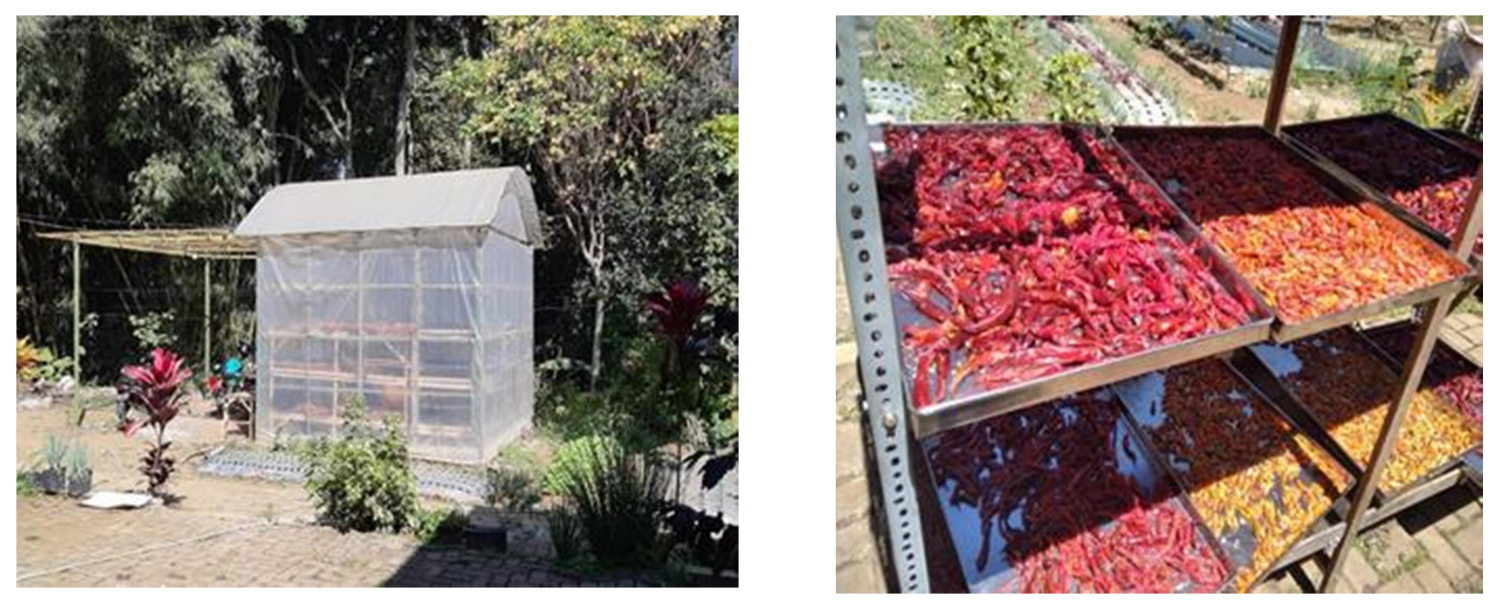

Gambar 6. Proses Pengeringan dengan Sinar Matahari

Pengeringan dengan vakum (vaccum dryer) kadar air bahan dikurangi dengan menguapnya di bawah atmosfer. Metode pengeringan ini biasanya digunakan untuk bahanbahan sensitif terhadap panas (Armand, 2006; Yulia, 2014). Dengan keadaan, demikian tipe vakum cocok digunakan sebagai alat pengering bahan pangan seperti cabai. Pengeringan cabai besar dan cabai rawit dapat dilakukan dengan dua cara, yaitu dengan bantuan cahaya matahari atau dengan alat cabinet dryer. Waktu yang digunakan apabila memakai alat cabinet dryer adalah kurang lebih 8 jam sedangkan menggunakan bantuan sinar matahari untuk cabai besar adalah kurang lebih 3 hari. Pengeringan dengan cabinet dryer membutuhkan waktu yang lebih singkat dari menggunakan sinar matahari. Pengering cabinet dryer dapat menggunakan tenaga listrik atau gas, sebagaimana disajikan pada Gambar 7.

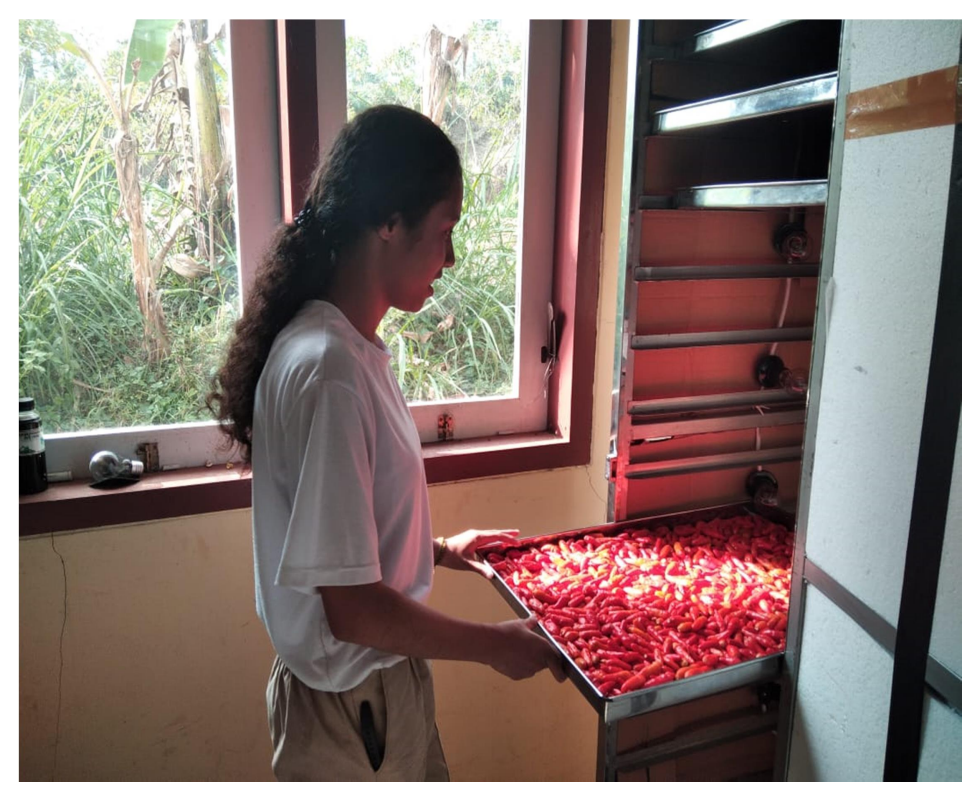

Gambar 7. Pengeringan dengan cabinet dryer 


\section{f. Penggilingan kasar}

Penggilingan cabai besar dan cabai rawit dilakukan dengan menggunakan blender. Pada saat cabai dihaluskan dengan blender harus benar-benar diperhatikan waktu saat penghalusan ini. Jangan sampai terlalu halus dan juga terlalu kasar. Waktu yang dibutuhkan kurang lebih 3 menit untuk menghaluskan cabai. Penggilingan dapat dilakukan dengan alat penggiling yang banyak di pasaran.

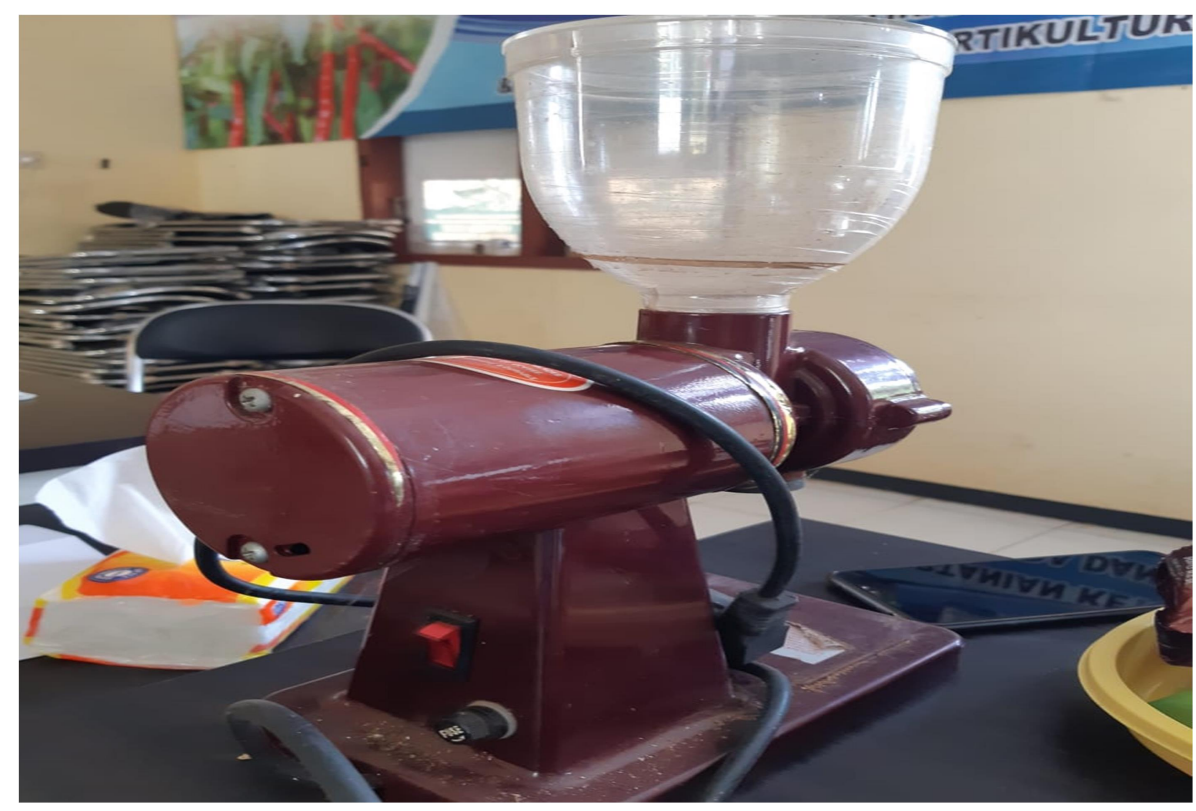

Gambar 8. Mesin Penggiling Cabai Kering menjadi Cabai Bubuk

\section{h. Pengemasan}

Pengemasan merupakan suatu cara dalam memberikan kondisi sekeliling yang tepat bagi bahan pangan dan dengan demikian membutuhkan pemikiran dan perhatian yang besar daripada yang biasa-biasanya diketahui. Industri pangan cenderung untuk membedakan antara proses pengalengan dan pembotolan disuatu pihak lain (Buckle dkk., 1985). Setiap jenis plastik memiliki sifat yang berbeda dalam ketahanannya ditembus oleh uap air dan gas (oksigen). Menurut Buckle, et al (1989), sifat-sifat daya tembus plastik dipengaruhi oleh suhu, ketebalan lapisan, orientasi dan komposisi, kondisi atmosfer (seperti RH, untuk pemindahan uap air) dan faktor lainnya. Jenis plastik tersusun dari polimer-polimer yang memiliki keunggulan dan kelemahan dari masing-masing jenis plastik, berbeda kemampuannya menyerap uap air. Berikut pengemasan dan penimbangan produk abon cabai, disajikan pada Gambar 9. 
Pelatihan dan Pendampingan Petani Cabai dalam Pengolahan Cabai Kering di Desa Bocek, Kecamatan Karangploso, Kabupaten Malang Evi Nurifah Julitasari, Emma Budi Sulistiarini, Yovita Serat Payon

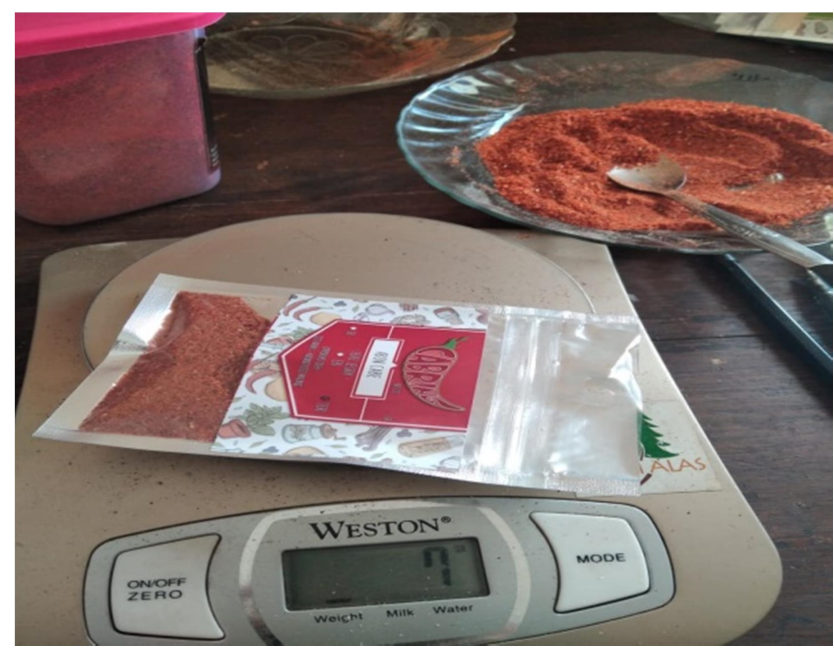

\section{Gambar 9. Pengemasan dan Penimbangan Berat Bersih}

\section{i. Penyimpanan}

Sebaiknya tempat penyimpanan adalah gudang yang bersih, memiliki sirkulasi udara yang baik, suhu tidak melebihi $30^{\circ} \mathrm{C}$, jauh dari bahan lain yang dapat menyebabkan kontaminasi, dan terbebas dari hama di gudang. Perlu diperhatikan bahwa sumber utama kerusakan adalah air, kelembaban, sinar matahari langsung, dan hama seperti kayu, rayap dan tikus. Abon cabai ini memiliki daya tahan selama 3-6 bulan jika disimpan pada suhu kamar dan menggunakan kemasan plastik. Namun, jika mengggunakan kemasan aluminium foil dan disimpan pada suhu kamar juga maka daya tahannya lebih panjang, kurang 2 tahun.

\section{KESIMPULAN DAN SARAN}

Pemberdayaan dan peningkatan kapasitas petani di daerah sentra untuk mengolah produknya menjadi produk olahan yang mempunyai nilai jual tinggi perlu selalu dilakukan. Seperti yang dilakukan tim pengabdi dari Universitas Widyagama Malang, melakukan pelatihan dan pendampingan pembuatan cabai basah menjadi cabai kering, sehingga terbukti menghasilkan peningkatan pendapatan bagi petani, selain lebih awet umur pakai cabai.

Pemberdayaan dan peningkatan kapasitas petani di daerah-daerah sentra, dapat dilakukan dengan melibatkan Penyuluh Pertanian Lapang (PPL) dan Kelompok Wanita Tani (KWT). 


\section{UCAPAN TERIMA KASIH}

Atas terselenggaranya kegiatan ini kami mengucapkan terima kasih kepada Ketua LPPM Universitas Widyagama Malang Ir.Gigih Priyandoko, MT.Phd, Koordinator Balai Penyuluh Pertanian (BPP) Karang Ploso Ir. Creasna bersama perangkatnya, mahasiswa Agribisnis yang telah membantu atas pelaksanaan pengabdian kepada masyarakat ini, dan beberapa pihak yang tidak bisa kami sebutkan satu persatu.

\section{DAFTAR PUSTAKA}

Apriyati, Erni. 2014. Teknilogi Pengolahan Abon Cabai . Yogyakarta.

Iffan Maflahah (2010). Studi Kelayakan Industri Cabai Bubuk di Kabupaten Cianjur. Embriyo Vo.7 no.2. ISSN 0216-0188. Fakultas Pertanian Universitas Trunojoyo.

Dewi Setyo Utari (2018) Analisis faktor-faktor yang mempengaruhi keputusan petani dalam menerapkan pola usahatani tumpangsari cabai merah dengan cabai rawit hibrida (studi kasus di desa Bocek, kecamatan Karangploso, kabupaten Malang). http://library.unisma.ac.id/slims_unisma/index.php?p=show_detail\&id=29752

Edowai, Desi Natalia. 2016. Mutu Cabai Rawit (Capsicum Frutescens L) Pada Tingkat Kematangan Dan Suhu Yang Berbeda Selama Penyimpanan. Sulawesi Utara.

Guntur Pribadi, Rizal Perlambang CNAWP, (2018). Peningkatan Kesejahteraan Petani Cabai dengan Pelatihan Pembuatan dan Pengemasan Abon dan Bubuk Cabai di Desa Tanjung Rejo Kecamatan Wuluhan Kabupaten Jember. Seminar Nasional Hasil Penelitian dan Pengabdian Kepada Masyarakat, 2018. ISBN 978602 14917-51..Hal 59-63

I Dewa Gede Agung ( 2019 ). Analisis Usahatani Cabai Merah (Capsicum Annum L) Di Desa Perean Tengah, Kecamatan Baturiti, Kabupaten Tabanan. https://media.neliti.com/media/publications/43823-ID-analisis-usahatani-cabaimerah-capsicum-annum-1-di-desa-perean-tengah-kecamatan-b.pdf

Kurniati, Novitri, DKK. 1 juni 2019. Teknologi Pengolahan Cabai Merah Bagi Kelompok Wanita Tani Desa Sukasari Kabupaten Kepahiang. Bengkulu: Jurnal Akses Pengabdian Indonesia (JAPI)

Kesumawati, Neti dan Hayati, Rita. 2016. Diversifikasi Produk Olahan Cabai Merah Keriting Sebagaiu Penanganan Pasca Panen Cabai Merah. Bengkulu

Luxkey, Reringga, DKK. 27-29 Agustus. Kajian Proses Pengeringan Cabai Merah (Capsicum annum L) Menggunakan Maltodekstrin dan Aplikasinya dalam Pembuatan Abon Cabai. Fakultas Pertanian Universitas Jambi: Semirata BKS Wilayah Barat.

Novitri Kurniati, Jafrizal, Fithri Mufriantie (2019). Teknologi Pengolahan Cabai Merah Bagi Kelompok Wanita Tani Desa Sukasari Kabupaten Kepahiang. Jurnal Akses Pengabdian Indonesia, Volume 4, Nomor 1, Juni 2019, e-ISSN 2548-346, Hal 12-17.

Renate, Dharia. 1 maret 2009. Pengemasan Puree Cabai Merah Dengan Berbagtai Plastik Yang Dikemas Vakum. Jambi.

Rachman, Chairul. 2009. Standar Prosedur Operasional (SPO) Pengolahan Cabai: Direktur Pengolahan Hasil Pertanian.

Soekartawi 1999. Analisis Usahatani, Cetakan ke 2, UI-Press, Jakarta (ISBN: 979- 456$132-0$

Suryana Achmad, dkk., 1990. Diversifikasi Pertanian dalam Proses Mempercepat Laju Pembangunan Nasional. Pustaka Sinar Harapan. Jakarta. 
Pelatihan dan Pendampingan Petani Cabai dalam Pengolahan Cabai Kering di Desa Bocek, Kecamatan Karangploso,

Sudiyono, Armand, 2002. Pemasaran Pertanian. UMM-Press.

Syamsul Rahman, 2015. Analisis Nilai Tambah Agroindustri Chips Jagung. Jurnal Aplikasi Teknologi Pangan 4 (3) 2015

Taufik Ridiyanto dkk (2018). Analisis Usahatani Cabai Merah (Capsicum Annum L.) Varietas Hot Beauty (Studi Kasus di Desa Sukamaju Kecamatan Cihaurbeuti Kabupaten Ciamis. Jurnal Ilmiah Mahasiswa. AGROINFO GALUH, p-ISSN 23564903, e-ISSN 2579-8359. 3(2), https://jurnal.unigal.ac.id/index.php/agroinfogaluh/article/view/706

Wilda Mikasari. 2016. Laporan Akhir Tahun Peningkatan Nilai Tambah Komoditas Cabai Melalui Penerapan Inovasi Teknologi Penyimpanan Dan Pengeringan Di Provinsi Bengkulu. BPTP Bengkulu, Balai Penelitian dan Pengembangan Pertanian.

Wijayanto editor (2020). Pasokan Tak Stabil, Harga Cabai di Pasar Tradisional Fluktuatif [Online]. Tersedia pada https://radarsurabaya.jawapos.com/read/2020/04/10/188141/pasokan-tak-stabilharga-cabai-di-pasar-tradisional-fluktuatif [ 10 April 2020]

Widiya Tri Astuti dkk. Analisis Nilai Tambah Dan Risiko Rantai Pasok Komoditas Cabai Merah Keriting (Capsicum annum L.) Di Kabupaten Cianjur, Jawa Barat. http://etd.repository.ugm.ac.id/home/detail_pencarian/161671

Wulandari, Wiwik Tri (2017) Analisis Efisiensi Teknis Dan Tingkat Pendapatan Usahatani Cabai Merah (Studi Kasus Di Desa Bocek Kecamatan Karangploso Kabupaten Malang). Sarjana thesis, Universitas Brawijaya.

Yudhaningsih, Aristy Fajar. 2012. Produksi Pembuatan Abon Cabai Naga. Surakarta: Digilib.uns.ac.id. 